ISSN 2072-4292

www.mdpi.com/journal/remotesensing

Article

\title{
Evaluating the Quality and Accuracy of TanDEM-X Digital Elevation Models at Archaeological Sites in the Cilician Plain, Turkey
}

\author{
Stefan Erasmi $^{1, *}$, Ralph Rosenbauer ${ }^{2}$, Ralf Buchbach ${ }^{1}$, Thomas Busche $^{3}$
} and Susanne Rutishauser ${ }^{2}$

1 Institute of Geography, Georg-August-Universität Göttingen, Goldschmidtstr. 5, D-37077 Göttingen, Germany; E-Mail: ralf.buchbach@stud.uni-goettingen.de

2 Institute for Archaeological Sciences, Universität Bern, Länggass-Strasse 10, CH-3012 Bern, Switzerland; E-Mails: ralph.rosenbauer@iaw.unibe.ch (R.R.); rutishauser@iaw.unibe.ch (S.R.)

3 Microwaves and Radar Institute, German Aerospace Center (DLR), D-82234 Wessling, Germany; E-Mail: Thomas.Busche@dlr.de

* Author to whom correspondence should be addressed; E-Mail: serasmi@uni-goettingen.de; Tel.: +49-551-39-8003; Fax: +49-551-39-8020.

External Editor: Prasad S. Thenkabail

Received: 1 April 2014; in revised form: 19 September 2014 / Accepted: 23 September 2014 / Published: 8 October 2014

\begin{abstract}
Satellite remote sensing provides a powerful instrument for mapping and monitoring traces of historical settlements and infrastructure, not only in distant areas and crisis regions. It helps archaeologists to embed their findings from field surveys into the broader context of the landscape. With the start of the TanDEM-X mission, spatially explicit 3D-information is available to researchers at an unprecedented resolution worldwide. We examined different experimental TanDEM-X digital elevation models (DEM) that were processed from two different imaging modes (Stripmap/High Resolution Spotlight) using the operational alternating bistatic acquisition mode. The quality and accuracy of the experimental DEM products was compared to other available DEM products and a high precision archaeological field survey. The results indicate the potential of TanDEM-X Stripmap (SM) data for mapping surface elements at regional scale. For the alluvial plain of Cilicia, a suspected palaeochannel could be reconstructed. At the local scale, DEM products from TanDEM-X High Resolution Spotlight (HS) mode were processed at $2 \mathrm{~m}$ spatial resolution using a merge of two monostatic/bistatic
\end{abstract}


interferograms. The absolute and relative vertical accuracy of the outcome meet the specification of high resolution elevation data (HRE) standards from the National System for Geospatial Intelligence (NSG) at the HRE20 level.

Keywords: TanDEM-X; alternating bistatic; synthetic aperture radar; SAR; Cilicia; digital elevation model; DEM

\section{Introduction}

The interpretation of remote sensing data has provided a useful tool in the support of archaeological field work for decades [1-4]. Besides reconnaissance flights during World War I, systematic acquisition of aerial photos played a major role in archaeological prospection, e.g., in Syria, already in the early 1920s and 1930s [5,6]. A major advance in land surface remote sensing started with the launch of the Landsat (formerly known as ERTS-1) satellites in the 1970s. However, the capability of those data for archaeological issues was quite poor due to the limits in spatial resolution. This is why a new era in archaeological remote sensing only started at the end of the 1990s with the availability of commercial and experimental very high resolution (VHR) spaceborne remote sensing systems [7]. At the same time, the declassification of the images from the CORONA program ("Key Hole" reconnaissance satellites of the CIA) also revolutionized archaeological remote sensing by providing relatively high resolution imagery from the mid 60 -ies to the early 70 -ies especially for the Near East $[8,9]$. The majority of systems operates in the optical domain and today is used routinely by scientists as a data source for the visual inspection of landscapes surrounding excavations or for the interpretation of surface remains of historical landscape patterns (e.g., hollow ways) [10-13]. The use of VHR satellite synthetic aperture radar (SAR) data in archaeology is quite new and only feasible with the start of new systems such as TerraSAR-X, RADARSAT-2 and Cosmo SkyMed in 2007. Nevertheless, archaeological applications of SAR remote sensing date back into the 1980s and were possible with the help of the experimental SAR-systems onboard the Space Shuttle missions (STS-2) or airborne platforms [14]. These studies demonstrated the huge potential of SAR for surface and subsurface land applications (e.g., [15,16]). However, they were limited in application for end users due to the experimental system design and the complexity of the processing chain and available software tools [17]. Recent archaeological campaigns were supported by the interpretation of amplitude images from medium resolution spaceborne SAR like ENVISAT-ASAR and ALOS-PALSAR [18-20]. Compared to this, the present VHR SAR systems provide operational data products and worldwide coverage at high temporal frequency and spatial resolution. Recent studies have underlined the substantial potential of VHR SAR for the recognition of archaeological features and historical morphological structures (e.g., [21,22]). Others have demonstrated the added value of SAR features like polarimetry and multifrequency for the identification of buried objects $[23,24]$.

The major advantage of SAR over optical data, besides the weather independency, is the ability to penetrate the topsoil layer in the magnitude of multiple wavelengths and hence the opportunity to detect buried archaeological features when vegetation cover is absent. Another factor in SAR analysis is the capability to capture the earth surface in $3 \mathrm{D}$ by means of interferometric SAR (InSAR). The 
basic configuration used for InSAR processing is an across-track interferometer which resembles the stereo-composition in optical remote sensing. In across-track formation, two SAR-sensors fly on parallel tracks and thus view the earth surface from two slightly different directions (see e.g., [25] for details). High resolution digital elevation models (DEMs) have been available before from optical stereo data acquired by airborne or spaceborne earth observation systems like, e.g., SPOT but the data are generally inhomogeneous due to restrictions of optical satellite data (i.e., cloud cover and illumination). First results based on InSAR processing were achieved during the Space Shuttle SIR-C/X-SAR missions in 1994 and with ESA's ERS-1 and ERS-2 systems [26]. The first homogenous and validated DEM of the land surface from InSAR processing resulted from the Shuttle Radar Topography Mission (SRTM) [25,27]. However, the SRTM DEM products showed some restrictions regarding coverage $\left(56^{\circ} \mathrm{S}\right.$ to $\left.60^{\circ} \mathrm{N}\right)$, data gaps (SRTM-X band) and resolution. Here, a major advance in SAR remote sensing was the extension of the TerraSAR-X system with a twin-satellite in 2010 flying in close formation (TanDEM-X, TerraSAR-X add-on for Digital Elevation Measurements) [28,29]. This constellation enables the acquisition of highly accurate across-track interferograms for the computation of InSAR products. The primary goal of the TanDEM-X mission is the generation of a worldwide, consistent and high precision global digital elevation model (DEM) at $12 \mathrm{~m}$ resolution [30]. Further, TanDEM-X data can be exploited by scientists in order to demonstrate innovative SAR techniques and applications using different interferometric configurations together with different imaging modes and polarizations of the sending and receiving radar wave [29].

In archaeology, high resolution DEM data are of utmost importance for the exploitation of landscapes with regard to remnants of ancient settlements and geomorphologic elements. The outstanding value of InSAR DEMs has been demonstrated by [15] who detected ancient Maya settlement structures based on an airborne InSAR campaign. Besides InSAR, the full SAR potential can be exploited by the use of differential SAR interferometry (DInSAR) for the detection of subsurface archaeological structures [31].

The present study investigates the potential of VHR SAR data for the mapping and 3D-modeling of landscape elements around an ancient site in the Plain of Cilicia, Turkey. The focus of research here is on the quantitative evaluation of the accuracy of experimental InSAR DEM products at the landscape (regional) and local scale. To do this, we collected all freely available DEM products for the study area (SRTM/C V.4.1, SRTM/X, ASTER Global DEM V.2) and compared them with different DEM products that were processed from TanDEM-X experimental imaging modes. Calibration and validation of height accuracy was based on an extensive high precision RTK-GPS field survey. The research design aims at answering the question whether experimental TanDEM-X data products in general are useable for identifying and monitoring archaeological sites and its surrounding landscape for future applications of this technology in remote or crisis areas. To do this, we identify known archaeological and landscape objects in the TanDEM-X products within the study area. From the technical point of view, we address the topic of height error measurements in experimental TanDEM-X DEM products by means of the absolute and relative vertical accuracy of elevation data. 


\section{Study Area}

The landscape of the Cilician Plain, today's Çurukova, is bordered to the West and North by the Middle Taurus Range. In the East the plain is closed off by the Amanus mountain range and the Gulf of Iskenderun and the Gulf of Mersin forms its southern boundary. Several rivers, originating in the Taurus Mountains cross the lowlands and discharge into the Mediterranean (Figure 1).

Figure 1. Overview of the broader study area of the Cilician Plain (Çurukova, Turkey) with locations of the most important ancient settlements. The frames indicate the extent of the TanDEM-X data for the site of Magarsos (Cape Karataş) (grey = TanDEM-X Stripmap; white $=$ TanDEM-X high resolution Spotlight mode; background: SRTM-C V4.1).

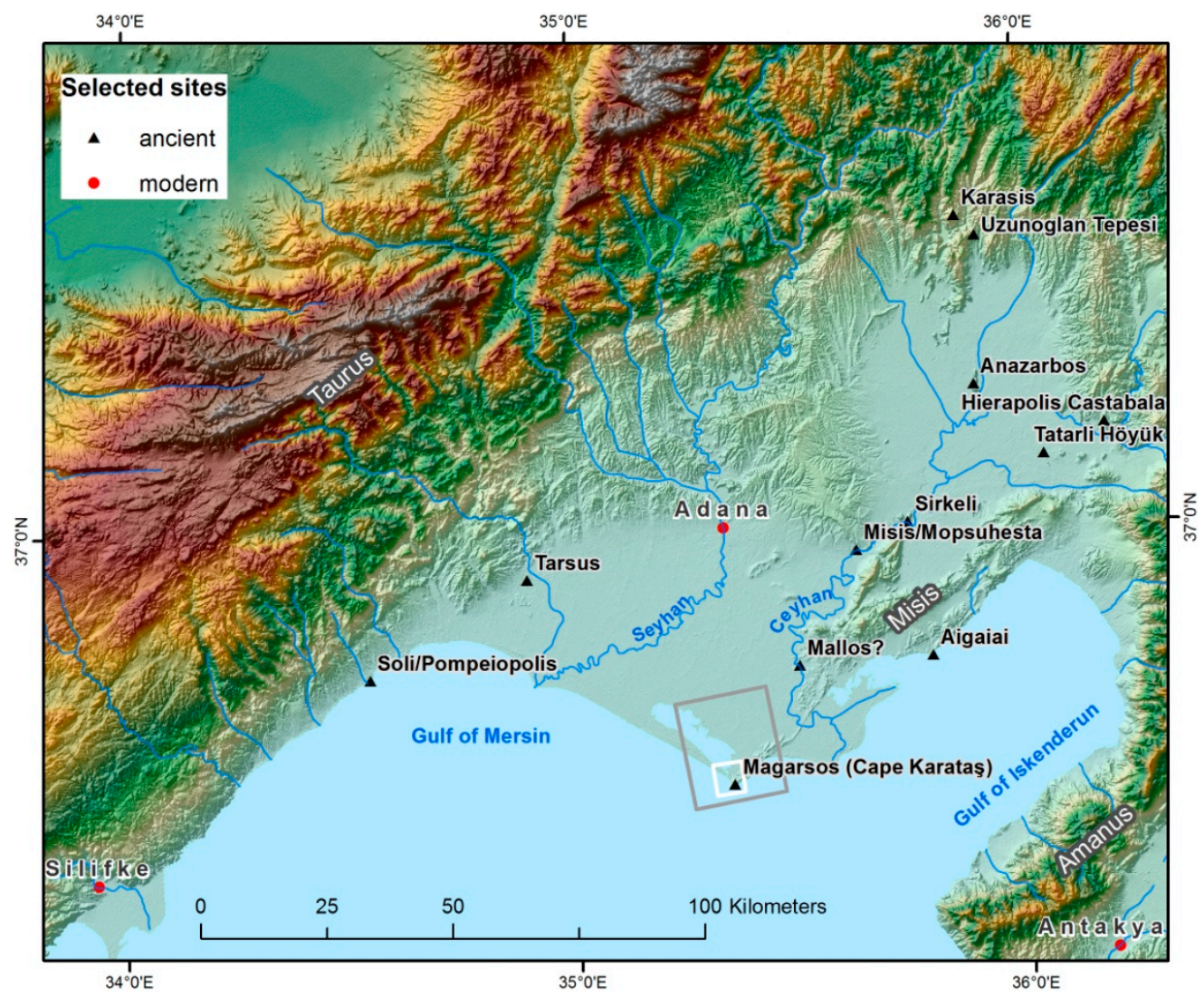

Since 2005, the Institute for Archaeological Sciences at the University of Bern has participated in research cooperation with the Istanbul Üniversitesi and the Onsekiz Mart Üniversitesi Çanakkale to explore the archaeological sites within the province of the Cilicia Pedias (lat.) today Adana district in Turkey. A particular focus is placed on the combination of high resolution remote sensing (using optical and SAR satellite imagery) and exemplary investigations of prominent sites by archaeological surveys and excavations. The aim of this combined approach is to get a better understanding of the interaction of landscape development and settlement activity. A sanctuary of Athena Magarsia was located at Cape Karataş at the southernmost point of the Cukurova Plain. During the Hellenistic period the site developed into a prosperous fortified seaport [32,33]. For the settlement area of Magarsos a high resolution elevation model is available from a high-precision RTK-GPS field survey. Combining it with data from geophysics (georadar, geomagnetics, geoelectrics) the antique city could be reconstructed in parts. 
Additionally, based on CORONA images of the American Keyhole Project one could even analyze already destroyed archaeological findings.

\section{Data and Methods}

\subsection{Satellite Data and Pre-Processing}

The TanDEM-X system is a spaceborne radar interferometer that is based on two TerraSAR-X radar satellites flying in close formation. The instruments on both satellites are advanced high resolution X-band SARs (9.65 GHz), which can be operated in different imaging modes (High Resolution Spotlight, Stripmap, ScanSAR) with full polarization capability (see [34] for a complete description of the system parameters). The TanDEM-X mission started its operational data acquisition in December 2010.

The interferometric data acquisition with the TanDEM-X satellite formation can be achieved in four different operational modes (bistatic, monostatic, alternating bistatic, simultaneous transmit) that can be combined with the different imaging modes [35]. In monostatic mode, the two satellites are operated independently meaning that each satellite transmits and records its own signal. The basic principle of the bistatic mode which serves as a standard for the operational global DEM acquisition is that only one satellite (TSX or TDX) serves as a transmitter whereas the backscattered signal is recorded by both satellites simultaneously. In our study, the alternating bistatic mode was used. In this mode, the transmitter between the two satellites is switched on a pulse-to-pulse basis. The backscattered signal from the ground is then again recorded by both receivers simultaneously. Hence, the alternating bistatic mode generates two monostatic and two bistatic SAR images during a single pass of the satellite formation (see [30] for details).

The primary mission objective of TanDEM-X is the generation of a worldwide DEM for a wide range of scientific and commercial applications at $12 \mathrm{~m}$ spatial resolution (TanDEM-X DEM). Further, advanced and innovative SAR techniques and applications are tested in experiments by the scientific user community (secondary mission goals). For this purpose, a limited amount of data is acquired in constrained time windows by the German Aerospace Center (DLR). The availability of the raw TanDEM-X data to the scientists enables the experimental processing of DEM products for case studies at significantly higher resolution compared to the final global TanDEM-X DEM. For this study, two TanDEM-X acquisitions were made possible in two different imaging modes at horizontal polarization. In Stripmap (SM) mode, the wider study area (approx. $18 \times 18 \mathrm{~km}^{2}$ ) was covered at an azimuth resolution of $2.54 \mathrm{~m}$. The High Resolution Spotlight (HS) mode enabled the registration of the excavation site and its surroundings (approx. $5 \times 5 \mathrm{~km}^{2}$ ) at a nominal resolution of $1.13 \mathrm{~m}$ in azimuth. The full description of the product parameters for the two acquisitions is given in Table 1.

Other satellite data included freely available DEM products from the shuttle radar topography mission (SRTM) as well as the ASTER Global DEM V.2. In this study, SRTM C-band version 4.1 (90 $\mathrm{m}$ resolution) and SRTM X-band data at $30 \mathrm{~m}$ resolution were used. SRTM C-band and ASTER Global DEM were obtained from [36]. SRTM-X band data were available from German Aerospace Center (DLR) [37]. All DEMs are provided in geographic coordinates with elevation values given in meters. Ellipsoidal heights as well as horizontal coordinates are related to the WGS84 datum. Further, a WorldView-2 pansharpened scene was used as background data for visualization. 
Table 1. Characteristics of available TanDEM-X acquisitions.

\begin{tabular}{ccc}
\hline Imaging Mode & Stripmap (SM) & \multicolumn{2}{c}{ High Resolution Spotlight (HS) } \\
\hline Interferometric Mode & \multicolumn{2}{c}{ alternating bistatic } \\
\hline Polarization Mode & \multicolumn{2}{c}{ Single $(\mathrm{HH} / \mathrm{HH})$} \\
\hline Incidence Angle & 33.7 & 57.7 \\
\hline Effective baseline $(\mathrm{m})$ & 86.57 & 210.12 \\
\hline Slant range res. $(\mathrm{m})$ & 0.91 & 0.45 \\
\hline Azimuth spacing $(\mathrm{m})$ & 2.54 & 1.13 \\
\hline Acquisition date & 16.02 .2012 & 20.08 .2012 \\
\hline Data product type & Co-registered Single Look Slant Range Complex (CoSSC) \\
\hline
\end{tabular}

TanDEM-X raw data were processed by the TanDEM-X ground segment of DLR following an operational processing chain. The most important functionality of this pre-processing is the bistatic SAR focusing of the image pairs to Co-registered Single Look Slant Range Complex (CoSSC) products. Further processing included the phase unwrapping, multi-looking, re-flattening, phase-to-height conversion and geocoding of the slant range data. An explanation of the theory of SAR processing is beyond the scope of this paper. A detailed review of SAR interferometry is given by [26]. Here, our particular emphasis was on the appropriate selection of the reference DEM for the interferogram flattening which has considerable impact on phase unwrapping and hence on the quality of the final DEM product. Another focus of the processing was on the evaluation of the alternating bistatic mode. We customized a workflow that was proposed by [30] in order to maximize the phase stability and phase-to-height sensitivity for DEM processing. In a first step, a combination of one monostatic and one bistatic image from TDX and TSX was used in order to generate an across-track interferogram and a preliminary DEM product (ALT-1). This product was then used as reference for the interferogram generation of the opposite monostatic/bistatic image pair (ALT-2, see Figure 2). The interferometric processing of the two independent monostatic images was not fully supported by the software package (ENVI/SarScape 4.4) at the time of finalizing this manuscript and could not be evaluated.

Figure 2. Graph of the interferometric workflow for the TanDEM-X DEM generation.

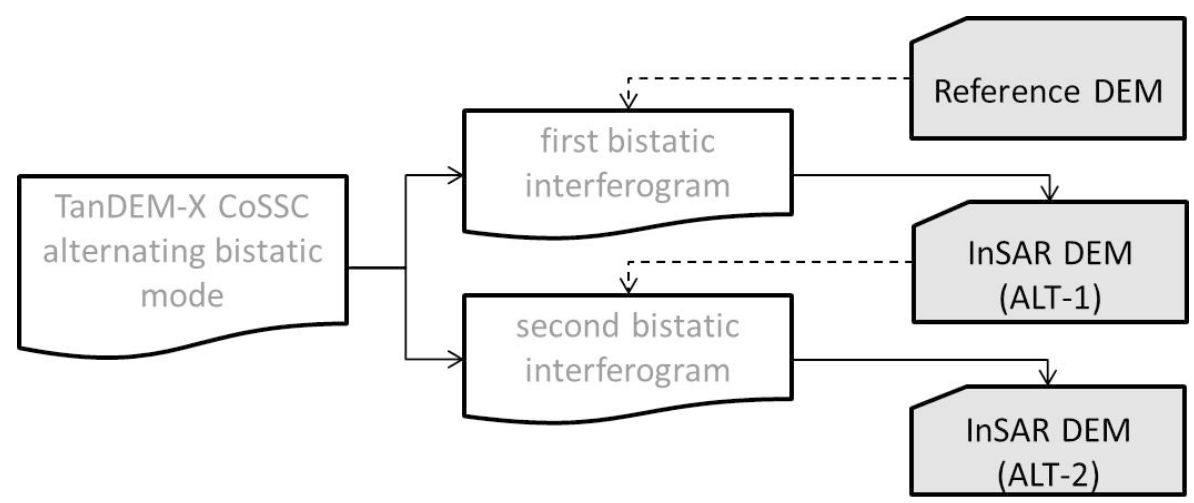

The same workflow was applied to both, the HS and the SM imaging mode of TanDEM-X. In case of the SM mode, a gap-filled SRTM C-band DEM was used as reference for the first interferogram (SM-ALT-1). The primary reference for the ALT-1 interferogram in the HS processing workflow (HS-ALT-1) was the final Stripmap InSAR DEM (SM-ALT-2). 
In summary, four InSAR DEMs were generated for the study area at two different scales (SM-ALT-1/-2, HS-ALT-1/-2). At the landscape scale, the experimental geocoded Stripmap DEM products were produced at $7 \mathrm{~m}$ pixel spacing. The local scale DEM products from the HS imaging mode were resampled at $2 \mathrm{~m}$ resolution.

As a by-product to all TanDEM-X DEM products, the coherence and backscatter layers were also geocoded to the cartographic reference system (WGS1984 UTM Zone 36 North). Radar backscatter values were radiometrically calibrated to sigma nought backscattering coefficients. Both products were used as auxiliary information in the visual interpretation of the study area.

\subsection{RTK GPS Field Survey}

A detailed archaeological field survey accompanied by a high precision geodetic survey was carried out at the ancient site of Magarsos (Cape Karataş) in summer 2009. The geodetic survey included archaeological features as well as topographic elements of the site and the surrounding landscape. All in all 11,275 GPS points were recorded. With reference to the manufacturer of the RTK-GPS system (Leica GPS 1200 GX1230GG), the horizontal accuracy (mean height error) of the measurements is about $20 \mathrm{~mm}$, the vertical accuracy (mean positional error) about $30 \mathrm{~mm}$. For this study, the total of the GPS points was reduced to a validation dataset of 7760 points based on the requirements and limitations for the comparison with satellite based DEM products. The omitted points include small archaeological features (e.g., excavations, profiles) as well as some natural and artificial objects where the recorded height information is related to the ground and would not be seen from the top in satellite DEMs (e.g., trees, buildings). In addition, areas of missing values in one of the DEM products were skipped.

\subsection{Statistical Analysis}

The assessment of the DEM accuracy was undertaken based on the computation of the absolute height error, which is defined as the difference between the value of the respective experimental DEM product and the reference height measured in the field. Accordingly, the overall absolute vertical accuracy $(\mathrm{AV})$ is expressed in terms of the root mean square height error:

$$
A V=\sqrt{\sum_{i=0}^{n}\left(Z_{D E M}-Z_{\text {ref }}\right)^{2} / n}
$$

In the equation, $Z_{D E M}$ represents the modeled DEM value, $Z_{\text {ref }}$ denotes the reference height from the RTK-GPS field survey and $n$ indicates the number of observations available for the validation.

Besides the AV, a second aspect of quality and accuracy in DEMs is the consideration of the relative or point-to-point height errors. Whereas AV mainly accounts for systematic errors or differences between data sources, the relative vertical accuracy (RV) is more related to random noise in the data ([38]). The relative vertical accuracy of DEM data is especially important when derivatives of the height values (e.g., slope, aspect) are subject to analysis. For the calculation of the RV, each point in the reference dataset was processed and the nearest neighbor in the dataset was identified. Then, the elevation at each point (for both, the DEM and the reference dataset) as well as the distance between the points was recorded. The RV was computed by the following equation adapted from [38]: 


$$
R V=\sqrt{\sum_{i=0}^{n}(\Delta r e f-\Delta D E M)^{2} / n}
$$

where, $\Delta r e f=\mid$ difference in reference elevation $\mid$

$\triangle D E M=\mid$ difference in DEM value $\mid$

All calculations of absolute and relative height errors were carried out on the entire reference dataset of 7760 valid points out of the RTK-GPS field survey. The presented results are valid within a $95 \%$ confidence interval ( $p$-value).

\section{Results and Discussion}

\subsection{Quality Assessment/Visual Interpretation of TanDEM-X DEM Products}

The final DEM from the TanDEM-X Stripmap product (bistatic 2) is visualized in Figure 3 together with a RGB color composite image from the same acquisition. The color composite is generated based on the coherence and backscatter information from the monostatic and bistatic channels (TDX/TSX) of the Stripmap product $($ Red = coherence; Green = mean Intensity; Blue = intensity difference between the monostatic and the bistatic radar backscatter). It illustrates the regular mosaic of the agricultural landscape in the hinterland as well as the dune and Macchia formations in the western coastal area. For reasons of visualization, the color ramps of the composite layers in the figure have been inverted, meaning that high values for coherence, intensity and difference are represented in low intensities for the respective color. As a consequence, Blue and Cyan areas in the composite image represent the zones of high intensity and high coherence, like, e.g., shallow water areas, agricultural fields and bare land. In opposite, Red areas symbolize area of low coherence and consequently high intensity difference, like vegetated areas and regions with steep slopes, e.g., the escarpments along the coast of Cape Karataş. In general, the coherence-intensity color composite provides a good base for the characterization of the landscape around the prehistoric site in the study area.

The TanDEM-X Stripmap DEM complements the color composite in terms of a general overview of the surface topography. It depicts clearly the Misis mountain range and even the minor height variability within the shrubland formation at the western coast of Cape Karataş as well as the decline from the shrubland to the hinterland and the lagoon are clearly evident. From the point of view of the archaeologist, the most remarkable phenomenon in the DEM image is the detection of a curvilinear structure that shows a very smooth rise in height in comparison to the surroundings (see darker green meandering feature from north to south in Figure 3). This structure can be associated to a palaeochannel of a former riverbed crossing the area from north to south and discharging into the Mediterannean Sea north of the ancient site of Magarsos after carving into the Misis mountains. This palaeochannel is assumed to form part of the ancient course of the river Seyhan. Compared to the present (see Figure 1) the river changed its course dramatically within late Holocene and now flows in the Mediterranean Sea approximately $40 \mathrm{~km}$ west of Cape Karataş. This is in accordance with findings from $[39,40]$ who detected different periods of quaternary sedimentation related to sea level variations and regional tectonics in the Cilicia basin. The positive height anomalies in the former river course are explained by the nature of emergence of such riverbeds that form river side dams (natural levees) under subtropical conditions which can be observed for the present course of the river Seyhan. After separation the 
former river between the natural levees was filled with colluvial sediments and forms a slight elevation compared to the surrounding landscape. Comparable features were also detected from SRTM data by [41] in southern Iraq but the level of detail of the TanDEM-X Stripmap DEM allows for a more detailed analysis of the shape and depth of those objects (see Figure 4). Today, the riverbed and floodplain is fully sedimented and the fertile soils provide the ground for intensive agricultural production.

Figure 3. Overview of the wider study area in the Cilician Plain, Turkey, using TanDEM-X Stripmap products. (a) RGB color composite (Red = coherence; Green = mean Intensity; Blue $=$ intensity difference between the monostatic and the bistatic radar backscatter; inverted color ramps, see explanation in text). (b) TanDEM-X Stripmap DEM (bistatic 2) resampled to $7 \mathrm{~m}$ resolution. The white frame indicates the extent of the TanDEM-X HS products.
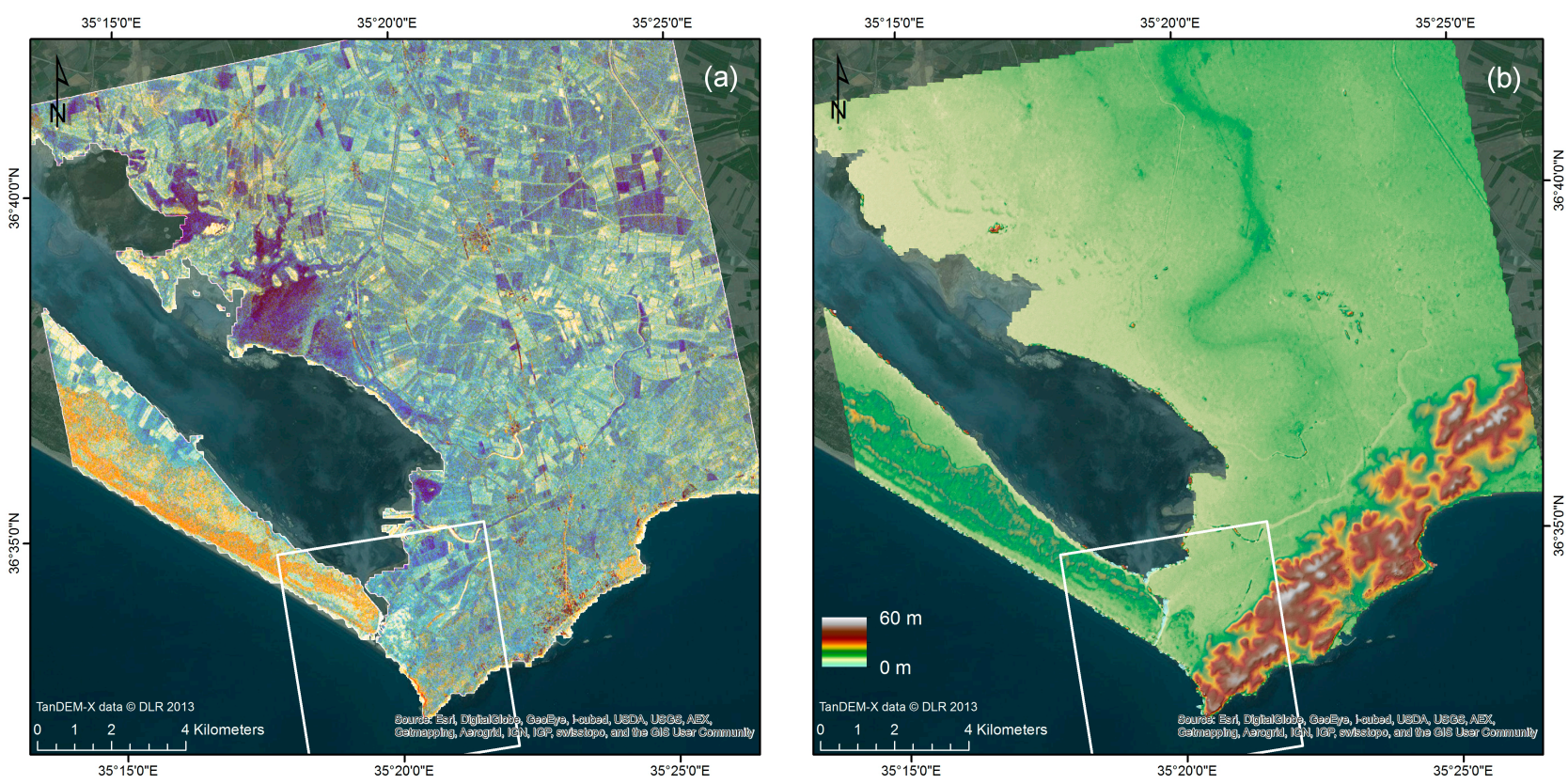

Figure 4. Cross profiles of height values extracted from TanDEM-X Stripmap and SRTM-C DEM data. The black line indicates the position of the profile.

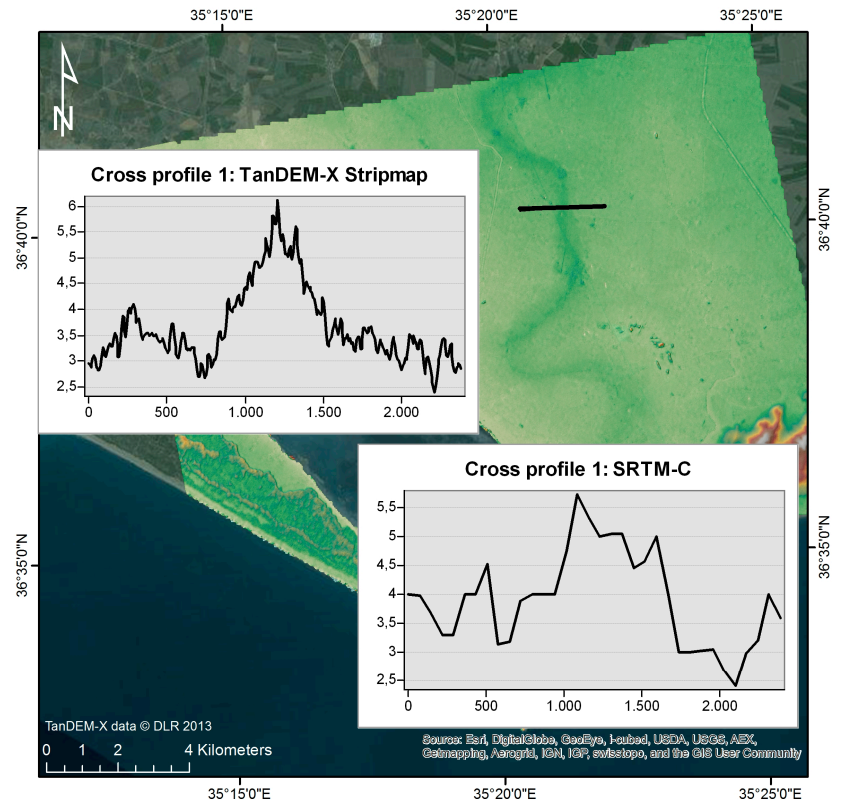


The precise reconstruction of the former course of the river Seyhan supports investigations on several important questions related to the historical topography of the Cilician Plain. Several ancient writers describe topographical situations referring to the course of rivers. Even descriptions of military campaigns [42] are not understandable without the knowledge of the ancient environment. An important resource for localizing ancient sites so far are so-called "itineraria" that convey route descriptions for travelers and merchants $[43,44]$. In this genre, the names of sites and cadastral sections are listed in the sequence that they had to be passed. In addition even the river crossings are mentioned. Thus, the localization of historic sites is closely linked to knowledge about ancient fluvial systems and TanDEM-X Stripmap data can help to improve the understanding of historical landscapes.

Not only at the landscape scale but even intra-site the TanDEM-X HS DEM reveals traces of archaeological features. Figure 5 shows the settlement area of Magarsos as a result of the on site archaeological prospection. The $2 \mathrm{~m}$ resolution TanDEM-X HS DEM processed for the settlement area together with a slope map is shown in Figure 6. The most remarkable remain to be recognized is the course of the city wall at the northern side of the settlement area of Magarsos. Even the position of fortification towers and city gates can be recognized. At the southern side the characteristic shapes of theater and stadium are represented in the DEM. Compared to other remote sensing data sources and virtual globes that are also applicable for the detection of archaeological features (e.g., VHR satellite images in GoogleEarth), the exploitation of satellite SAR data is not limited by weather conditions constraints. In addition, the SAR is less sensitive to vegetation and might see ground surface features that are sometimes covered by biomass. LIDAR (light detection and ranging) is a prominent tool for high precision topographic surveys and yields unachievable resolution and accuracy compared to SAR. However, LIDAR sensors are only available on airborne platforms and the use is mostly restricted in remote and crisis areas.

Figure 5. Overview of the settlement area of Magarsos (Cape Karataş) during the 2nd settlement phase (2nd century BC).




Figure 6. TanDEM-X HS products for the study area around Cape Karataş. (a) DEM and hillshade model (bistatic 2) resampled to $2 \mathrm{~m}$ resolution; (b) Slope.


\subsection{Accuracy Assessment of TanDEM-X Experimental DEM Products}

All TanDEM-X experimental DEM products were evaluated with regard to absolute and relative vertical accuracy as described in the methods section. The overview in Figure 7 shows the final DEM for the TanDEM-X HS ALT-2 product resampled at $2 \mathrm{~m}$ resolution. Absolute height values range between sea level and $60 \mathrm{~m}$ above sea level. The morphology is characterized by the foothills of the Misis mountains, gently descending into the hinterland of the alluvial plain. Seawards, the foothills fall steeply to the sea and form the present shape of Cape Karataş. On the right of Figure 7, the residuals of the AV are mapped for the whole reference dataset. Compared to the left side, low to medium residuals $(<2 \mathrm{~m})$ can be clearly associated with the foothills and shallow landforms of the area. Highest residuals are mainly found at the cape and the adjacent shoreline of Cape Karataş.

When the height values of the RTK-GPS field survey are plotted against the data from the TanDEM-X HS experimental products, the impact of the optimized interferometric processing using the alternating bistatic information is evident (Figure 8). The plot on the left-hand side includes DEM values after standard processing (ALT-1) using another, coarse resolution input DEM as reference (here: SRTM-C V4). On the right, the interferometric workflow was adjusted by using the first DEM (ALT-1) as reference for processing the second (ALT-2). The scatterplots and accompanied statistics not only underline the improved fitting of the TanDEM-X HS ALT-2 product in terms of coefficient of determination and spreading of height values around the regression line. It is also obvious from the plots that the alternating bistatic merge processing results in a significant decrease in the offset of the regression line $(4.75$ to $0.93 \mathrm{~m}$ ) and thus reduces the systematic error in absolute height estimation from TanDEM-X HS data. The remaining systematic error of $0.93 \mathrm{~m}$ is assumed to be a consequence of the introduced errors from the interferometric processing workflow using the SRTM C-band DEM in a first step and the resulting TanDEM-X bistatic ALT-1 product as input. 
Figure 7. Accuracy assessment of TanDEM-X HS alternating bistatic (ALT-2) DEM for the study area around Cape Karataş. The color of the dots represents the residuals (absolute height errors) of final DEM compared to RTK-GPS field survey.



Figure 8. Linear correlation between RTK-GPS field survey and TanDEM-X HS absolute height values. (a) TanDEM-X bistatic processing (ALT-1); (b) TanDEM-X alternating bistatic merge processing (ALT-2).
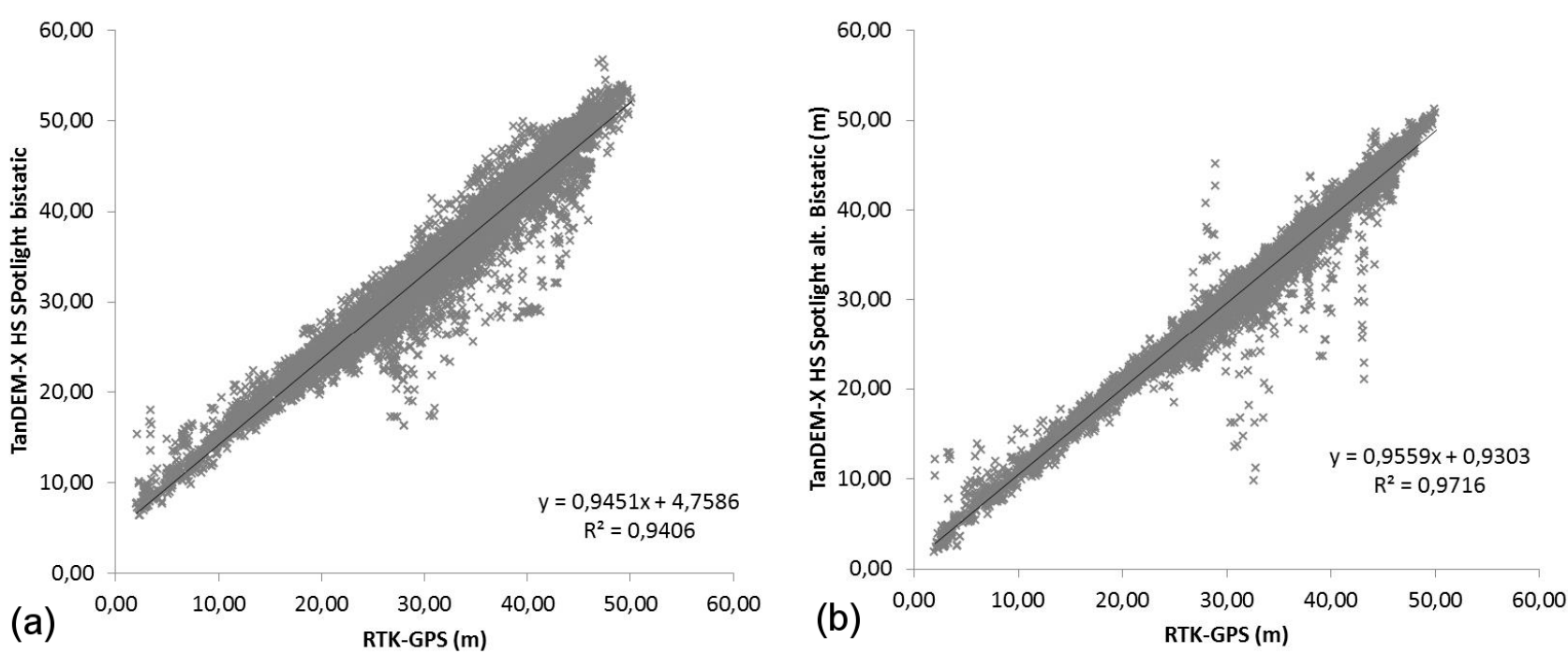

A closer look at the AV for the different tested experimental DEM products is given in Table 2 . Besides the four experimental TanDEM-X products, the table includes a comparison with existing, lower resolution DEM products that are available for the study area. The AV values for all TanDEM-X 
products are clearly below the errors for the two global DEM products (SRTM_C, ASTER GDEM). Out of this, the SRTM C-band DEM performs significantly better in terms of AV compared to the ASTER GDEM. Furthermore, the SRTM X-band DEM yields comparable results to the TanDEM-X Stripmap as well as to the Spotlight ALT-1 products. A significant enhancement in AV is observed for the ALT-2 products, as already mentioned above. This trend is consistent for both tested TanDEM-X imaging modes and yields height errors that are almost three times lower compared to the standard processing. Lowest errors are achieved for the TanDEM-X Stripmap ALT-2 DEM with a pixel spacing of $7 \mathrm{~m}$ and an AV of $1.61 \mathrm{~m}$. If the sample of observations is reduced to all points with a slope of less than 20 percent, the AV can even be reduced to $1.24 \mathrm{~m}$. AV values for all other DEM products in Table 2 are also significantly lower if only flat areas are evaluated.

The comparison of the relative height errors or random noise in terms of RV in Table 2 confirms the general trends from the AV with highest errors for global DEM products. On the other hand, the RV of the SRTM X-band DEM is lower than the RV of the TanDEM-X Stripmap products. Lowest relative height errors are obtained for TanDEM-X HS products independent of the applied processing (ALT-1/-2). Again, height errors decrease when steep areas are neglected.

Table 2. Mean absolute vertical accuracy $(A V$ in $\mathrm{m})$ and relative vertical accuracy ( $R V$ in $\mathrm{m})$ of all evaluated DEM products compared to the RTK-GPS field survey. The values in brackets indicate the resampled resolution of the final DEM product.

\begin{tabular}{ccccc}
\hline DEM Product (Resolution) & AV (all) & AV(<20\% Slope) & RV (all) & RV (<20\% Slope) \\
\hline SRTM_C $(90 \mathrm{~m})$ & 7.23 & 6.08 & 1.81 & 1.67 \\
\hline SRTM_X $(30 \mathrm{~m})$ & 4.68 & 4.03 & 0.82 & 0.84 \\
\hline ASTER GDEM V.2 $(30 \mathrm{~m})$ & 11.61 & 10.48 & 1.72 & 1.62 \\
\hline TanDEM-X SM, ALT-1 $(7 \mathrm{~m})$ & 4.12 & 3.88 & 1.41 & 0.95 \\
\hline TanDEM-X SM, ALT-2 $(7 \mathrm{~m})$ & 1.61 & 1.24 & 1.05 & 0.74 \\
\hline TanDEM-X HS, ALT-1 $(2 \mathrm{~m})$ & 4.95 & 4.25 & 0.66 & 0.63 \\
\hline TanDEM-X HS, ALT-2 $(2 \mathrm{~m})$ & 1.80 & 1.40 & 0.74 & 0.67 \\
\hline HREG* (former HRTI-3) $(12 \mathrm{~m})$ & 12.40 & & 6.2 & \\
\hline HRE80 * $(8 \mathrm{~m})$ & 8.00 & & 4 & \\
\hline HRE40 $(4 \mathrm{~m})$ & 4.00 & & \\
\hline HRE20 $(2 \mathrm{~m})$ & 2.00 & & \\
\hline
\end{tabular}

* HRE stands for High Resolution Elevation Data. It is intended to provide a product specification for the high resolution elevation datasets stored by the National System for Geospatial Intelligence (NSG) (see [45]). It thus provides a standard for the comparison of DEM quality and accuracy.

Absolute and relative vertical errors of all tested products are well below the errors of global DEM products like, e.g., SRTM _C and ASTER GDEM. The combination of two interferograms from the alternating bistatic mode of TanDEM-X Stripmap enables DEM generation with height accuracies that are in the range of higher level definitions proposed by the National System for Geospatial Intelligence (NSG) [45]. Here, the processed TanDEM-X Stripmap DEM (ALT-2) meets the requirements of the HRE80 standard in terms of spatial resolution, absolute and relative vertical accuracy (see Table 2). Compared to this, the specification of the standard TanDEM-X global DEM is adapted to the former HRTI-3 standard (HREG, see Table 2 and [30]). 
Of course, all results of the comparison of height values in grid cells with RTK-GPS point measurements have to be critically assessed with regard to factors like cellsize, slope and vegetation. e.g., the coarse grid cells of SRTM C-band include one or many RTK-GPS points which makes sense on flat terrain but might be critically on steep slopes where multiple ground observations per DEM grid cell are required. In our study, the network of ground observations enables the existence of at least nine RTK-GPS points for each SRTM C-band grid cell. Vegetation can impact the accuracy assessment when the field survey refers to the ground and satellite measurements relate to the top of canopy, e.g., it is documented, that the absolute accuracy of ASTER GDEM V.2 is a function of the land cover type where the presence of aboveground features causes a positive bias in the elevation data [46]. However, in the present study, all RTK-GPS validation points were limited to ground features and the land cover in the study area is dominated by arable and barren land with low canopy height or sparse vegetation. In general, the accuracy of height measurements from different SAR systems is a function of land cover type, slope, aspect and radar beam geometry. The penetration depth and hence, volume scattering of the radar wave in vegetation is higher in C- compared to X-band. Weydahl et al. [47] compared SRTM-X and SRTM-C band DEMs and demonstrated the relation between land cover type, radar wavelength and height errors. In general, the X-band height errors decreased from forest to lower canopies (e.g., agriculture). Based on these findings, in our case study, vegetation cover could have an impact on the comparability of absolute height errors between the TanDEM-X SM and HS DEMs. As can be seen from Table 1, the SM acquisition was in February and the HS data were acquired in August where vegetation height in agricultural fields (dominating crop: barley) is at its peak. Accordingly, the absolute height error (AV) is higher in the HS products compared to the SM DEMs despite the higher spatial resolution of HS elevation data. In contrast, the relative height error (RV) is not affected by the acquisition data and is considerably lower in the TanDEM-X HS compared to the SM DEM.

With regard to archaeological applications, spaceborne X-band data acquisitions in the winter term provide an unveiled view of the ground surface and topsoil layer which might support the recognition of buried objects. On the other hand, the existence of vegetation can also provide valuable information about subsurface structures that are causally related to changes in soil structure and vegetation growth (crop marks) as shown in other studies based on optical satellite data $[48,49]$.

In addition to the above mentioned factors, AV and RV are dependent on other preprocessing parameters, like, e.g., multilooking. In general, multilooking is used to improve the signal-to-noise ratio and reduces artifacts like speckle in the processed SAR data and derived products. A higher multilooking smoothes the SAR image and is accompanied by a lower spatial resolution of the final product. Hence, multilooking should be suitable to reduce systematic and random errors in SAR data. In Table $3 \mathrm{AV}$ and RV values are summarized for different multilooking scenarios. Lowest absolute and relative height errors are observed for a multilooking of two in azimuth and four in range direction. 
Table 3. Mean absolute vertical accuracy $(A V$ in $\mathrm{m})$ and relative vertical accuracy $(R V$ in $\mathrm{m})$ of TanDEM-X HS DEM (ALT-2) compared to RTK-GPS field survey for different multilooking scenarios.

\begin{tabular}{cccc}
\hline Multilooking Factors (Azimuth/Range) & AV (all) & RV (all) & Resampled Resolution (m) \\
\hline $1 / 2$ & 2.82 & 1.95 & 1 \\
$2 / 4$ & 1.80 & 0.74 & 2 \\
$3 / 6$ & 1.97 & 0.79 & 3 \\
$4 / 8$ & 1.94 & 0.98 & 4 \\
\hline
\end{tabular}

\section{Conclusions}

As part of the TanDEM-X Science mission, raw TanDEM-X data in different imaging modes are exclusively available to scientific users for the evaluation of new scientific applications of satellite based high resolution InSAR products. Against this background, we evaluated the suitability of different experimental across-track TanDEM-X acquisitions with regard to applications in archaeology for a test site in the Cilician Plain, Turkey. In addition to the Stripmap mode, which represents the standard imaging mode for the generation of the global TanDEM-X DEM, here, for the first time, High Resolution Spotlight mode TanDEM-X data were acquired and made available for scientific use in archaeology. The interferometric processing of the SAR data yielded DEMs that were evaluated at the landscape (7 m pixel spacing) and at the local scale (2 m pixel spacing) with regard to quality for visualization and in addition concerning accuracy in terms of absolute and relative height error.

The visual interpretation of the processed TanDEM-X Stripmap DEM clearly revealed a palaeochannel that could be linked to the river Seyhan. Such findings are also possible by using global freely available DEM data (e.g., SRTM), however, the resolution and quality of TanDEM-X Stripmap is far beyond those data and it supports archaeologists to more precisely allocate their records to the surrounding landscape and to understand the historical topography and settlement patterns. At the local scale, the potential of TanDEM-X High Resolution Spotlight DEM products for the identification of ancient surface features could be demonstrated. Compared to the archaeological site map of the ancient settlement area of Magarsos, several linear structures of the buried ancient city wall together with towers and gates are evident in the hillshade and slope views of the $2 \mathrm{~m}$ InSAR DEM. The strengths of the High Resolution Spotlight DEM compared to high resolution optical satellite images are the ability of weather independent regular scheduling of data acquisitions and the ability to penetrate the top layer of the land surface. However, the level of detail in the delineation of small-scaled archaeological features is limited when compared to other remote sensing systems, e.g., airborne LIDAR.

Further to the quality of the TanDEM-X DEMs, the analysis of the accuracy of absolute and relative height measurements from both imaging modes proved the strength of the across-track imaging constellation of the TanDEM-X system with the unique alternating bistatic mode that enables simultaneous interferometric acquisitions from both sensors. Here, we introduced a new, simple workflow for the merge of two monostatic-/bistatic-interferograms that resulted in a significant reduction of both, absolute $(4.12 \mathrm{~m}$ to $1.61 \mathrm{~m})$ and relative height errors $(1.41 \mathrm{~m}$ to $1.05 \mathrm{~m})$ compared to the TanDEM-X Stripmap single across-track interferogram (bistatic mode). Further optimization of processing and adjusted 
sensor constellations (e.g., larger baseline) can provide even higher accuracy of height information compared to the achieved results [50,51] and should be subject to future research.

Overall, the results confirm the potential of both, the TanDEM-X High Resolution Spotlight and Stripmap mode for high precision 3-dimensional mapping of the earth surface. TanDEM-X is the first and only spaceborne across-track interferometric SAR system. The outcome of this first case study encourages the transfer of the proposed method to other cultural heritage sites, in particular in remote and conflict areas.

\section{Acknowledgments}

All TanDEM-X data were kindly provided by German Aerospace Center (DLR) within the project "The potential of Tandem-X DEM data for archaeological prospection — case studies in Plain Cilicia, Turkey" (project ID: OTHER0340).

\section{Author Contributions}

Stefan Erasmi, Ralph Rosenbauer and Susanne Rutishauser designed the concept for the case study. Ralf Buchbach and Thomas Busche performed the processing of the TanDEM-X data. Stefan Erasmi analyzed the data and wrote the paper. All authors contributed to the discussion of the results.

\section{Conflicts of Interest}

The authors declare no conflict of interest.

\section{References}

1. Crawford, O.G.S. Air-Photography for Archaeologists; Ordnance Survey: London, UK, 1929.

2. Fröhlich, S. Lufbildarchäologie in Sachsen-Anhalt; Fröhlich, S., Ed.; Landesamt für Denkmalpflege und Archäologie Sachsen-Anhalt: Halle, Germay, 1997.

3. Kennedy, D. Aerial archaeology in the Middle East: The role of the military-Past, present and future? In Aerial Archaeology Developing Future Practice; Bewley, R.H., Raczkowski, W., Eds.; IOS Press: Amsterdam, The Netherlands, 2001; Volume 337.

4. Wilson, D.R. Air Photo Interpretation for Archaeologists; The History Press: London, UK, 1982.

5. Stichelbaut, B. The application of First World War aerial photography to archaeology: The Belgian images. Antiquity 2006, 80, 161-172.

6. Wiegand, T. Wissenschaftliche Veröffentlichungen des Deutsch-Türkischen Denkmalschutz-Kommandos; Wiegand, T., Ed.; Walter de Gruyter: Berlin, Germany, 1920-1924.

7. Lasaponara, R.; Masini, N. Satellite remote sensing in archaeology: Past, present and future perspectives. J. Archaeol. Sci. 2011, 38, 1995-2002.

8. Casana, J.; Cothren, J. The CORONA atlas project: Orthorectification of CORONA satellite imagery and regional-scale archaeological exploration in the Near East. In Mapping Archaeological Landscapes from Space; Comer, D.C., Harrower, M.J., Eds.; Springer New York: New York, NY, USA, 2013; pp. 33-43. 
9. Ur, J.A. CORONA satellite imagery and ancient near eastern landscapes. In Mapping Archaeological Landscapes from Space; Comer, D.C., Harrower, M.J., Eds.; Springer New York: New York, NY, USA, 2013; pp. 21-31.

10. Brown Vega, M.; Craig, N.; Lindo, G.A. Ground truthing of remotely identified fortifications on the Central Coast of Peru. J. Archaeol. Sci. 2011, 38, 1680-1689.

11. Kaimaris, D.; Georgoula, O.; Patias, P.; Stylianidis, E. Comparative analysis on the archaeological content of imagery from Google Earth. J. Cult. Herit. 2011, 12, 263-269.

12. Lin, A.Y.-M.; Novo, A.; Har-Noy, S.; Ricklin, N.D.; Stamatiou, K. Combining GeoEye-1 satellite remote sensing, UAV aerial imaging, and geophysical surveys in anomaly detection applied to archaeology. IEEE J. Sel. Top. Appl. Earth Obs. Remote Sens. 2011, 4, 870-876.

13. Casana, J. Radial route systems and agro-pastoral strategies in the Fertile Crescent: New discoveries from western Syria and southwestern Iran. J. Anthropol. Archaeol. 2013, 32, 257-273.

14. Giardino, M.J. A history of NASA remote sensing contributions to archaeology. J. Archaeol. Sci. 2011, 38, 2003-2009.

15. Garrison, T.G.; Chapman, B.; Houston, S.; Roman, E.; Garrido Lopez, J.L. Discovering ancient Maya settlements using airborne radar elevation data. J. Archaeol. Sci. 2011, 38, 1655-1662.

16. McCauley, J.F.; Schaber, G.G.; Breed, C.S.; Grolier, M.J.; Haynes, C.V.; Issawi, B.; Elachhi, C.; Blom, R. Subsurface valleys and geoarcheology of the eastern Sahara revealed by shuttle radar. Science 1982, 218, 1004-1020.

17. Lasaponara, R.; Masini, N. Satellite synthetic aperture radar in archaeology and cultural landscape: An overview. Archaeol. Prospect. 2013, 20, 71-78.

18. Cigna, F.; Tapete, D.; Lasaponara, R.; Masini, N. Amplitude change detection with ENVISAT ASAR to image the cultural landscape of the Nasca Region, Peru. Archaeol. Prospect. 2013, 20, $117-131$.

19. Stewart, C.; Schiavon, G. ALOS PALSAR analysis of the archaeological site of Pelusium. Archaeol. Prospect. 2013, 20, 109-116.

20. Tapete, D.; Cigna, F.; Masini, N.; Lasaponara, R. Prospection and monitoring of the archaeological heritage of Nasca, Peru, with ENVISAT ASAR. Archaeol. Prospect. 2013, 20, $133-147$.

21. Linck, R.; Busche, T.; Buckreuss, S.; Fassbinder, J.W.E.; Seren, S. Possibilities of archaeological prospection by high-resolution X-band satellite radar-A case study from Syria. Archaeol. Prospect. 2013, 20, 97-108.

22. Bachofer, F.; Quénéhervé, G.; Märker, M. The delineation of paleo-shorelines in the lake Manyara basin using TerraSAR-X Data. Remote Sens. 2014, 6, 2195-2212.

23. Dore, N.; Patruno, J.; Pottier, E.; Crespi, M. New research in polarimetric SAR technique for archaeological purposes using ALOS PALSAR data. Archaeol. Prospect. 2013, 20, 79-87.

24. Patruno, J.; Dore, N.; Crespi, M.; Pottier, E. Polarimetric multifrequency and multi-incidence SAR sensors analysis for archaeological purposes. Archaeol. Prospect. 2013, 20, 89-96.

25. Rabus, B.; Eineder, M.; Roth, A.; Bamler, R. The shuttle radar topography mission-A new class of digital elevation models acquired by spaceborne radar. ISPRS J. Photogramm. Remote Sens. 2003, 57, 241-262.

26. Bamler, R.; Hartl, P. Synthetic aperture radar interferometry. Inverse Probl. 1998, 14, R1. 
27. Bamler, R.; Eineder, M.; Adam, N.; Zhu, X.; Gernhardt, S. Interferometric potential of high resolution spaceborne SAR. Photogramm. Fernerkund. Geoinf. 2009, 2009, 407-419.

28. Esch, T.; Taubenboeck, H.; Roth, A.; Heldens, W.; Felbier, A.; Thiel, M.; Schmidt, M.; Mueller, A.; Dech, S. TanDEM-X mission-New perspectives for the inventory and monitoring of global settlement patterns. J. Appl. Remote Sens. 2012, 6, 1-21.

29. Krieger, G.; Zink, M.; Bachmann, M.; Bräutigam, B.; Schulze, D.; Martone, M.; Rizzoli, P.; Steinbrecher, U.; Walter Antony, J.; de Zan, F.; et al. TanDEM-X: A radar interferometer with two formation-flying satellites. Acta Astronaut. 2013, 89, 83-98.

30. Krieger, G.; Moreira, A.; Fiedler, H.; Hajnsek, I.; Werner, M.; Younis, M.; Zink, M. TanDEM-X: A satellite formation for high-resolution SAR interferometry. IEEE Trans. Geosci. Remote Sens. 2007, 45, 3317-3341.

31. Morrison, K. Mapping subsurface archaeology with SAR. Archaeol. Prospect. 2013, 20, 149-160.

32. Rosenbauer, R. Topographisch-urbanistischer Survey des Ruinengeländes am Kap Karatas/Türkei. Vorbericht zur ersten Kampagne 2006. Hefte Archäol. Semin. Univ. Bern 2007, 20, 107-119.

33. Rosenbauer, R.; Sayar, M.H. Die Siedlungsmauer am Kap Karatas. Ein Indiz für die Stadtneugründung von Antiochia am Pyramos an der Stelle von Magarsos? In Hellenismus in der Kilikia Pedias; Hoffmann, A., Ed.; Ege Yayınlar1: İstanbul, Turkey, 2011; Volume 14, pp. 155-174.

34. Werninghaus, R.; Buckreuss, S. The TerraSAR-X mission and system design. IEEE Trans. Geosci. Remote Sens. 2010, 48, 606-614.

35. Bueso Bello, J.L.; Gonzalez, C.; Kraus, T.; Brautigam, B. Characteristics of TanDEM-X experimental modes. In Proceedings of the 2012 IEEE International Geoscience and Remote Sensing Symposium (IGARSS), Munich, Germany, 22-27 July 2012; pp. 1042-1045.

36. USGS-U.S. Geological Survey. EarthExplorer. Available online: http://earthexplorer.usgs.gov/ (accessed on 30 May 2014).

37. Deutsches Zentrum fuer Luft-und Raumfahrt e. V., German Aerospace Center (DLR). EOWEB-Earth Observation Data Service. Available online: https:/centaurus.caf.dlr.de:8443/ eoweb-ng/template/default/welcome/entryPage.vm (accessed on 30 May 2014).

38. Gesch, D.B. The national elevation dataset. In Digital Elevation Model Technologies and Applications: The DEM Users Manual, 2nd ed.; Maune, D.F., Ed.; American Society for Photogrammetry and Remote Sensing: Bethesda, MD, USA, 2007; pp. 99-118.

39. Walsh-Kennedy, S.; Aksu, A.; Hall, J.; Hiscott, R.; Yaltırak, C.; Çifçi, G. Source to sink: The development of the latest Messinian to Pliocene-Quaternary Cilicia and Adana Basins and their linkages with the onland Mut Basin, eastern Mediterranean. Tectonophysics 2014, 621, 1-21.

40. Dinc, U.; Senol, S.; Cangir, C.; Oguz Dinc, A.; Akca, E.; DIngil, M.; Oztekin, E.; Kapur, B.; Kapur, S. Soil survey and soil database of Turkey. In Soil Resources of Europe: Second Edition; Jones, R.J.A., Houskova, B., Bullock, P., Montanarella, L., Eds.; European Soil Bureau: Ispra, Italy, 2005; EUR 20559 EN, pp. 371-375.

41. Hritz, C.; Wilkinson, T.J. Using shuttle radar topography to map ancient water channels in Mesopotamia. Antiquity 2006, 80, 415-424.

42. Krämer, E.; Leggewie, O. Xenophon: Anabasis: Kommentar; Verlag Aschendorff: Münster, Germany, 1985. 
43. Miller, K. Itineraria Romana: Römische Reisewege an der Hand der Tabula Peutingeriana; Eigenverl. G. Husslein: Bregenz, Austria, 1988.

44. Spanu, M. La Cilicia nella Tabula Peutingeriana. In Palaia Philia: Studi di Topografia Antica in Onore di Giovanni Uggeri; Marangio, C., Laudizi, G., Uggeri, G., Eds.; M. Congedo: Galatina, Italy, 2009; Volume 4, pp. 635-652.

45. Heady, B.; Kroenung, G.; Rodarmel, C. High resolution elevation data (HRE) specification overview. In Proceedings of the Digital Mapping-From Elevation to Information, San Antonio 2009 ASPRS-MAPPS Fall Conference, San Antonio, TX, USA, 16-19 November 2009.

46. Gesch, D.; Oimoen, M.; Zhang, Z.; Meyer, D.; Danielson, J. Validation of the ASTER Global Digital Elevation Model Version 2 over the conterminous United States. Int. Arch. Photogramm. Remote Sens. Spatial Inf. Sci. 2012, XXXIX-B4, 281-286.

47. Weydahl, D.J.; Sagstuen, J.; Dick, Ø.B.; Rønning, H. SRTM DEM accuracy assessment over vegetated areas in Norway. Int. J. Remote Sens. 2007, 28, 3513-3527.

48. Rowlands, A.; Sarris, A. Detection of exposed and subsurface archaeological remains using multi-sensor remote sensing. J. Archaeol. Sci. 2007, 34, 795-803.

49. Agapiou, A.; Hadjimitsis, D.G.; Sarris, A.; Georgopoulos, A.; Alexakis, D.D. Optimum temporal and spectral window for monitoring crop marks over archaeological remains in the Mediterranean region. J. Archaeol. Sci. 2013, 40, 1479-1492.

50. Davidson, G.W.; Bamler, R. Multiresolution phase unwrapping for SAR interferometry. IEEE Trans. Geosci. Remote Sens. 1999, 37, 163-174.

51. Ferretti, A.; Prati, C.; Rocca, F. Multibaseline InSAR DEM reconstruction: The wavelet approach. IEEE Trans. Geosci. Remote Sens. 1999, 37, 705-715.

(C) 2014 by the authors; licensee MDPI, Basel, Switzerland. This article is an open access article distributed under the terms and conditions of the Creative Commons Attribution license (http://creativecommons.org/licenses/by/4.0/). 